Article

\title{
Optimization of Window Design for Daylight and Thermal Comfort in Cold Climate Conditions
}

\author{
Tony-Andreas Arntsen (D) and Bozena Dorota Hrynyszyn *(D) \\ Department of Civil and Environmental Engineering, Faculty of Engineering, NTNU-Norwegian University of \\ Science and Technology, Postboks 8900, 7491 Trondheim, Norway; tonyanda@stud.ntnu.no \\ * Correspondence: bozena.d.hrynyszyn@ntnu.no; Tel.: +47-73559528
}

Citation: Arntsen, T.-A.;

Hrynyszyn, B.D. Optimization of Window Design for Daylight and Thermal Comfort in Cold Climate Conditions. Energies 2021, 14, 8013. https://doi.org/10.3390/en14238013

Academic Editors: Geun Young Yun, Jin Woo Moon and Jonghoon Ahn

Received: 1 June 2021

Accepted: 14 July 2021

Published: 30 November 2021

Publisher's Note: MDPI stays neutral with regard to jurisdictional claims in published maps and institutional affiliations.

Copyright: (c) 2021 by the authors. Licensee MDPI, Basel, Switzerland. This article is an open access article distributed under the terms and conditions of the Creative Commons Attribution (CC BY) license (https:// creativecommons.org/licenses/by/ $4.0 /)$.

\begin{abstract}
Window design affects the overall performance of a building. It is important to include window design during the initial stages of a project since it influences the performance of daylight and thermal comfort as well as the energy demand for heating and cooling. The Norwegian building code facilitates two alternative methods for achieving a sufficient daylight, and only guidelines for adequate indoor thermal comfort. In this study, a typical Norwegian residential building was modeled to investigate whether the criteria and methods facilitate consistent and good performance through different scenario changes and furthermore, how the national regulations compare to European standards. A better insulated and more air-tight building has usually a lower annual heating demand, with only a marginal decrease in the daylight performance when the window design is unchanged. A more air-tight construction increases the risk of overheating, even in cold climates. This study confirms that a revision of the window design improves the overall performance of a building, which highlights the importance of proper window design. The pursuit of lower energy demand should not be at the expense of indoor thermal comfort considering the anticipated future weather conditions. This study indicates that criteria for thermal comfort and daylight, if clearly defined, can affect the energy demand for heating and cooling, as well as the indoor climate positively, and should be taken into account at the national level. A comparison between the national regulations and the European standards was made, and this study found that the results are not consistent.
\end{abstract}

Keywords: energy optimization; daylight; thermal comfort; IDA ICE

\section{Introduction}

Window design is an important aspect for the overall performance of a building. An unfortunate window design can turn a high-performance building into a building with poor energy performance. How this design is planned affects the energy efficiency in terms of both the annual heating demand and cooling demand, as well as the need for artificial lighting. The amount of solar radiation transmitting through the fenestration also affects the indoor environment. Having sufficient daylight provision influences the visual comfort of the occupants, and has been proved to have benefits on the well-being of the occupants [1]. Additionally, a good daylight design provides stimulating and well-lit indoor environments. Increased urban density contributes to a more challenging task to provide adequate daylight in living spaces. The surrounding buildings are obstructions to available daylight and may cause poor quality of day-lit spaces. Furthermore, this influences the visual and thermal comfort of the indoor environment. The problem with increased urban density should be considered already in the urban planning and regulations set by local authorities [2].

The solar radiation that hits the earth is equivalent to 15.000 times the total annual energy consumption for the entire Earth. This solar energy can be utilized either in a passive or active way. Using the solar heat gains through windows for space heating, and the solar radiation as a substitute for artificial lighting are examples of passive strategies [3]. Principles for active utilization could be solar thermal collectors that directly use of the 
solar energy to heat water that circulates in the building for space heating and domestic hot water. The conversion of solar energy to electricity by solar panels is also an example of active utilization [4]. Since Norway is an elongated country with various topography, the solar radiation is very dependent on location and season. Figure 1 illustrates the variation of solar irradiation in Norway for winter and summer conditions.

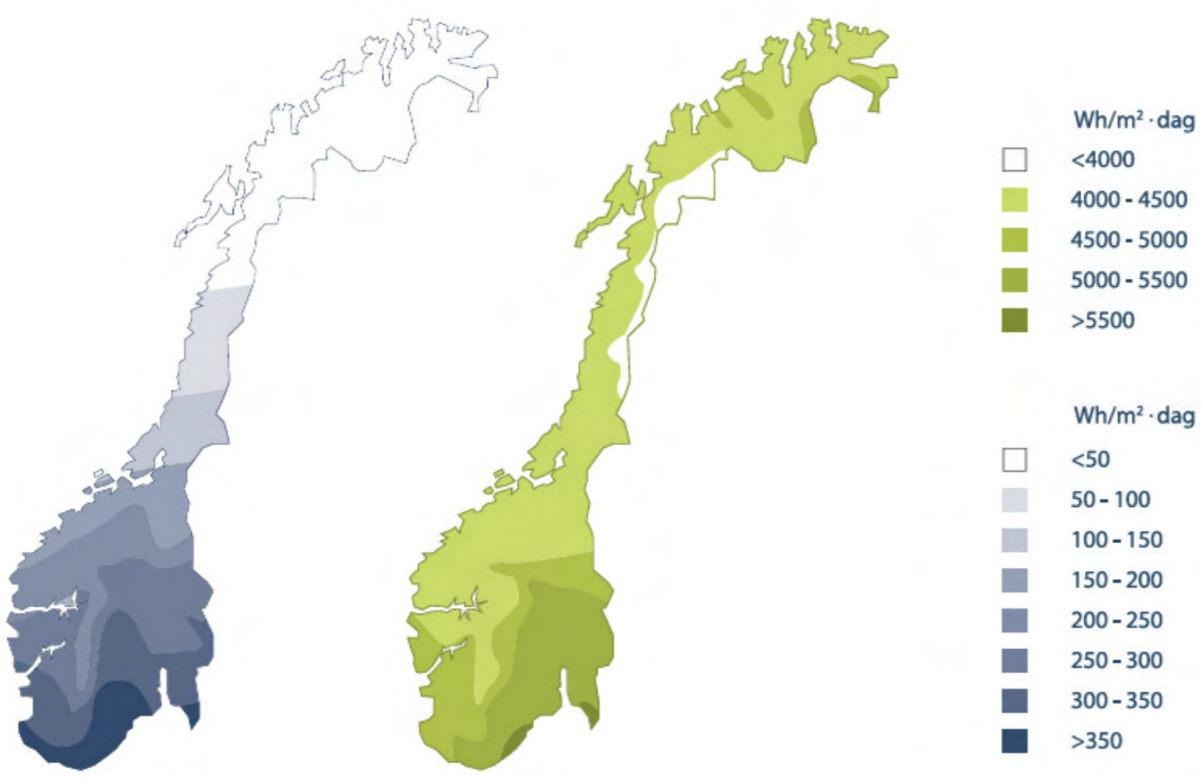

Figure 1. Daily solar irradiation on horizontal surface-January (left), July (right) [5].

Several studies found that daylight has a positive influence on human health and wellbeing. Daylight ensures many qualities both for the indoor environment and psychological wellbeing [6]. Daylight openings provide connection to the outside while also illuminating indoor surfaces. When human skin is exposed to sunlight, it produces vitamin $\mathrm{D}$, which is linked to several health benefits [7]. Lansdowne et al. [8] found that the body also produces serotonin, which helps in improving mood. A recent study discovered that a photoreceptor in the eye is sensitive to the wavelengths in the blue spectrum, which daylight naturally covers, and synchronizes our internal biological clock [9].

While numerous other European countries specify a minimum number of hours of solar exposure, the Norwegian government has decided to withdraw the paragraph concerning sunlight from the building code in the latest upgrade of the Norwegian technical requirements, TEK17 [10]. It is, therefore, imperative that the regulations define sufficient minimal criteria for the daylight provision. In a study by Ko et al. and Sepúlveda et al. [11] it was found that the Estonian daylight standard had limited reliability in predicting daylight, and there was a strong disagreement between the national and European standard. In 2019, the European standard concerning criteria for daylight in buildings (EN 17037) was implemented as a Norwegian standard. The standard encourages building designers to focus on providing sufficient daylight spaces, and also categorizes target ambitions with respect to daylight [12].

Thermal comfort is an important measurement in building design and affects how the occupants appreciate the indoor environment. On the other side, the occupant's behavior may have a direct impact on the building's energy consumption. Another critical aspect of thermal comfort is associated with the risk of overheating. Since thermal comfort is a subjective condition, it is hard to tell at which exact temperature overheating occurs, as it is dependent on the metabolic rate, uncertainties in body mass, fitness and blood flow [13]. With the anticipated increase in temperature due to climate change, buildings in cold climates face a future with an increased risk for overheating during summer [14]. Norway experienced a set of extreme heat waves in the summer of 2018 and 2019 [15]. Li et al. [16] 
conducted a study of indoor overheating risk for converted lofts in London. One of their findings was that passive adaptations were not sufficient enough to eliminate overheating, and it is likely that by the 2080s, active cooling will be a necessity. Tian and Hrynyszyn [17] found in their study that a retrofitting to higher energy standards by improving the airtightness of a building can increase the risk of overheating, even in cold climates. They highlighted that overheating should be paid more attention to based on the expected future climate conditions. Lee et al. [18] investigated how light shelves with applied photovoltaics could help to maximize building energy efficiency. Light shelves rotated 10 degrees toward the sun proved to be most efficient in terms of PV-production during summer conditions in South Korea.

Norwegian residential buildings are regulated by TEK17. It is, therefore, most relevant to use the given performance criteria for daylight and thermal comfort in this regulation as a scale of measure. The aim of this paper is to investigate how the criteria facilitate a consistent and good performance in terms of daylight and thermal comfort, and the comparison between the Norwegian national regulations and the European standards. The methodology of this study examines a set of parameter changes to an original case building. Each case is simulated in IDA ICE. The results of this study indicate how to optimize the design of the case building in terms of daylight and thermal comfort performance.

\section{Background}

\subsection{Norwegian Regulation}

The Norwegian Building Regulations, TEK17, consist of a set of minimum properties and technical requirements that have to be satisfied in order to build according to the regulations. This building code defines functional regulations and performance criteria with attached pre-accepted performance that fulfills these requirements.

\subsubsection{Thermal Comfort}

For thermal comfort, there are two functional requirements that are relevant to the design of residential dwellings. The following paragraphs are cited in TEK17:

\section{$\S 13-4(1):$}

The thermal indoor climate in rooms intended for continuous occupancy shall be regulated in a manner that promotes health and satisfactory comfort when the rooms are used as intended.

\section{$\S 13-4(2)$ :}

In rooms for continuous occupancy, it must be possible to open at least one external window or door.

\subsubsection{Daylight}

TEK17 indicates two functional requirements that are considered to be relevant for building design. The following paragraphs are cited from TEK17 [19].

$\S 13-7(1)$ :

Construction works shall have adequate access to light.

$\S 13-7(2):$

Rooms for continuous occupancy shall have adequate access to daylight. 
The pre-accepted performance for \$13-7 (2) gives two methods for achieving the required performance. The first method is based on the average daylight factor, DF, which has to be at a minimum of $2.0 \%$ for the most critical rooms. Calculations with the use of simulations software have to be validated according to CIE 171:2006 and the premises defined in NS-EN 12464-1:2011, Chapter 4.4. The following equation needs to be fulfilled for selected rooms [19]:

$$
\overline{D F}=2.0 \%
$$

The premises from the European light standard NS-EN 12464-1:2011 describe how the grid systems shall be created. The maximum grid size is defined by the following equation [20]:

$$
p=0.2 \times 5^{\log _{10}(d)}
$$

where:

$p=$ Maximum grid size $[\mathrm{m}]$

$d=$ Longer dimension of the calculation area

Alternatively, the daylight requirement can be achieved with a simplified method [19]:

$$
A_{g} \geq 0.07 \cdot A_{B R A} \cdot L T
$$

where:

$A_{g}=$ Glazing area $\left[\mathrm{m}^{2}\right]$

$A_{B R A}=$ Usable floor space, including area of protruding building parts $\left[\mathrm{m}^{2}\right]$

$L T=$ Light transmittance of the glass $[\%]$

\subsection{International Regulations}

To compare the Norwegian regulations, a set of representative European standards are examined.

\subsubsection{Thermal Comfort}

NS-EN 16798-1:2019 states that for defining the thermal environment, the criteria shall be based on the indices PMV-PPD from EN ISO 7730. For buildings without mechanical cooling, the criteria could either be specified by the default method from EN ISO 7730 or by using the adaptive method. The adaptive method also considers the adaptation effects for occupant behavior when experiencing thermal discomfort. This method applies to buildings with sedentary activities where the occupants can adapt to changing thermal conditions by either ventilating through windows or a change of clothing. The collected data material underlying this method is based on studies conducted in office buildings but the standard ensures that the method also is applicable for similar spaces, such as residential buildings, because they share similar activity levels. Figure 2 shows the acceptable operative temperature ranges for categories derived in Table 1. NS-EN 16798-1:2019 gives an approximate calculation method using the running mean temperatures for the past seven days:

$$
\Theta_{r m}=\left(\Theta_{e d-1}+0.8 \Theta_{e d-2}+0.6 \Theta_{e d-3}+0.5 \Theta_{e d-4}+0.4 \Theta_{e d-5}+0.3 \Theta_{e d-6}+0.2 \Theta_{e d-7}\right) / 3.8
$$




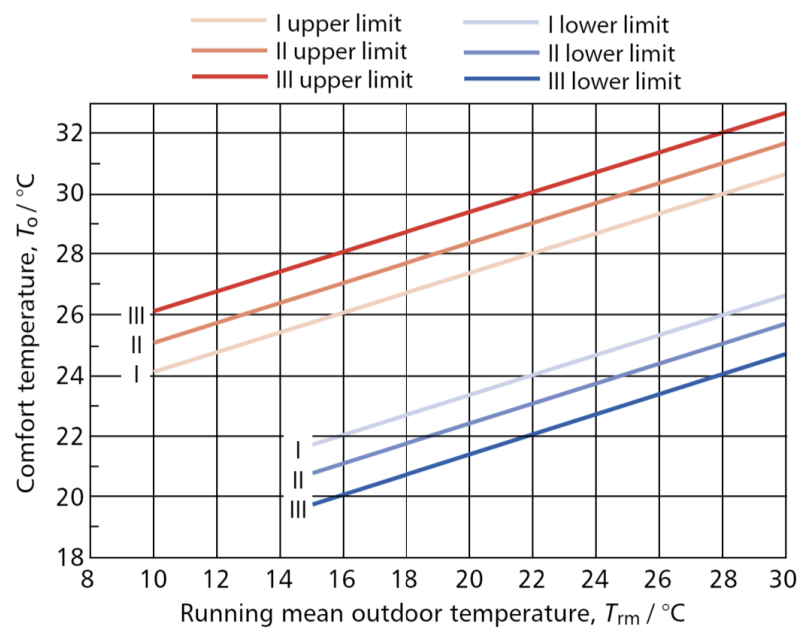

Figure 2. Acceptable operative temperature ranges based on temperatures from Table 1 [21].

Table 1. Adaptive comfort temperatures categories for free running buildings [22].

\begin{tabular}{cll}
\hline \multirow{2}{*}{ Category I } & upper limit & $\Theta_{\text {imax }}=0.33 \Theta_{r m}+18.8+2$ \\
\cline { 2 - 3 } Category II & lower limit & $\Theta_{\text {imin }}=0.33 \Theta_{r m}+18.8-3$ \\
\cline { 2 - 3 } & upper limit & $\Theta_{\text {imax }}=0.33 \Theta_{r m}+18.8+3$ \\
\hline \multirow{2}{*}{ Category III } & lower limit & $\Theta_{\text {imin }}=0.33 \Theta_{r m}+18.8-4$ \\
\cline { 2 - 3 } & upper limit & $\Theta_{\text {imax }}=0.33 \Theta_{r m}+18.8+4$ \\
\hline
\end{tabular}

\subsubsection{Daylight}

The European standard for Daylight in Buildings EN 17037:2018 is researched and prepared by Technical Committee CEN/TC 169 "Light and Lighting". The purpose of this paper is to facilitate a platform to secure adequate daylight provision in building design. The recommendations are divided into different ambition levels, addressing challenging interfaces against view out, glare and exposure to sunlight. The standard was verified as a Norwegian Standard in February 2019. Since it has authority as a Norwegian Standard, it will be referred to as NS-EN 17037:2018 further in this article.

The table cited from the standard, shown in Figure 3, gives recommended values based on desired level of ambition. The values for measurement is expressed in terms of illuminance measured in lux. Table A3 from NS-EN 17037:2018, shown in Figure 4, gives the corresponding daylight factor values for the respective CEN capital cities.

\begin{tabular}{|l|l|l|l|l|l|}
\hline $\begin{array}{l}\text { Level of } \\
\text { recommendation } \\
\text { for vertical and } \\
\text { inclined daylight } \\
\text { opening }\end{array}$ & $\begin{array}{l}\text { Target } \\
\text { illuminance } \\
E_{\mathrm{T}} \\
\mathrm{lx}\end{array}$ & $\begin{array}{l}\text { Fraction } \\
\text { of space } \\
\text { for target } \\
\text { level } \\
F_{\mathrm{plane}, \%}\end{array}$ & $\begin{array}{l}\text { Minimum target } \\
\text { illuminance } \\
E_{\mathrm{TM}} \\
\mathrm{lx}\end{array}$ & $\begin{array}{l}\text { Fraction of } \\
\text { space for } \\
\text { minimum } \\
\text { target level } \\
F_{\mathrm{plane}, \%}\end{array}$ & $\begin{array}{l}\text { Fraction of } \\
\text { daylight } \\
\text { hours } \\
F_{\text {time, }} \%\end{array}$ \\
\hline Minimum & 300 & $50 \%$ & 100 & $95 \%$ & $50 \%$ \\
\hline Medium & 500 & $50 \%$ & 300 & $95 \%$ & $50 \%$ \\
\hline High & 750 & $50 \%$ & 500 & $95 \%$ & $50 \%$ \\
\hline $\begin{array}{l}\text { NOTE Table A.3 gives target daylight factor }\left(D_{\mathrm{T}}\right) \text { and minimum target daylight factor }\left(D_{\mathrm{TM}}\right) \text { corresponding to } \\
\text { target illuminance level and minimum target illuminance, respectively, for the CEN capital cities. }\end{array}$ \\
\hline
\end{tabular}

Figure 3. Recommended values for daylight provision [12]. 


\begin{tabular}{|c|c|c|c|c|c|c|c|}
\hline Nation & Capital $^{\mathrm{a}}$ & $\begin{array}{l}\text { Geographi } \\
\text { cal latitude } \\
\varphi\left[^{\circ}\right]\end{array}$ & $\begin{array}{l}\text { Median } \\
\text { External } \\
\text { Diffuse } \\
\text { Illuminance } \\
E_{\mathrm{V}, \mathrm{d}, \text { med }}\end{array}$ & $\begin{array}{c}D \text { to } \\
\text { exceed } \\
100 \mathrm{~lx}\end{array}$ & $\begin{array}{c}D \text { to } \\
\text { exceed } \\
300 \mathrm{~lx}\end{array}$ & $\begin{array}{c}D \text { to } \\
\text { exceed } \\
500 \mathrm{~lx}\end{array}$ & $\begin{array}{c}D \text { to } \\
\text { exceed } \\
750 \mathrm{~lx}\end{array}$ \\
\hline Norway & Oslo & 59,90 & 12400 & $0,8 \%$ & $2,4 \%$ & $4,0 \%$ & $6,0 \%$ \\
\hline
\end{tabular}

Figure 4. Recommended values for daylight provision [12].

\section{Materials and Methods}

\subsection{Reference Model}

In this study, a typical Norwegian residential building is studied. Figure 5 displays a representative house model designed by Norgeshus. The total floor area is $140 \mathrm{~m}^{2}$ over two floors. Daily rooms, such as the kitchen, dining area and living room, are located on the ground floor, while bedrooms are situated on the first floor. See Figure 6 for the layout of the ground floor and Figure 7 for that of the first floor. The simulation is performed for the climate in Oslo, Norway.

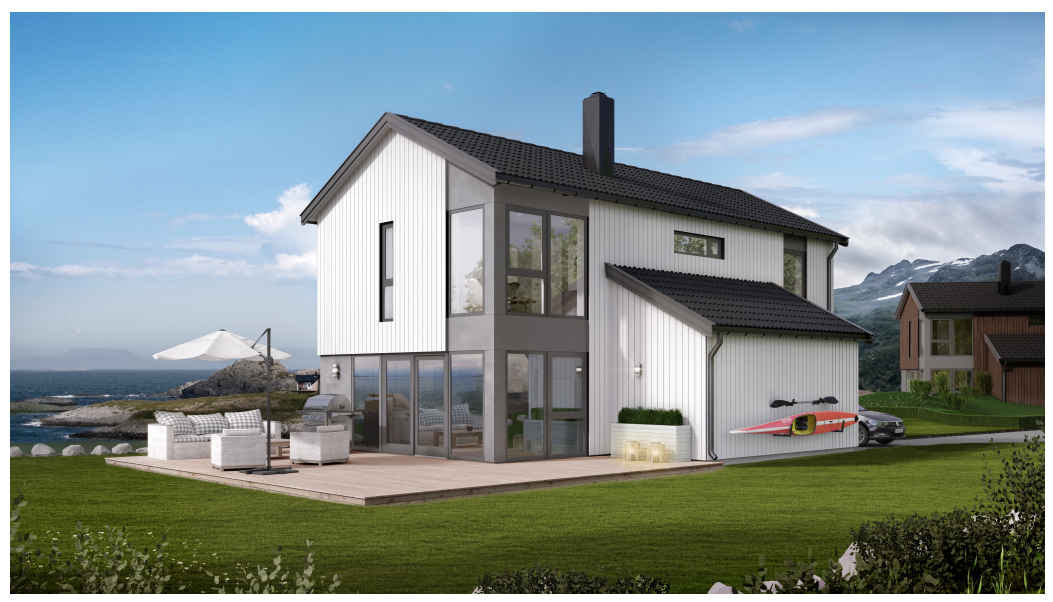

Figure 5. Case building representing a typical residential building in Norway (source: Norgeshus).

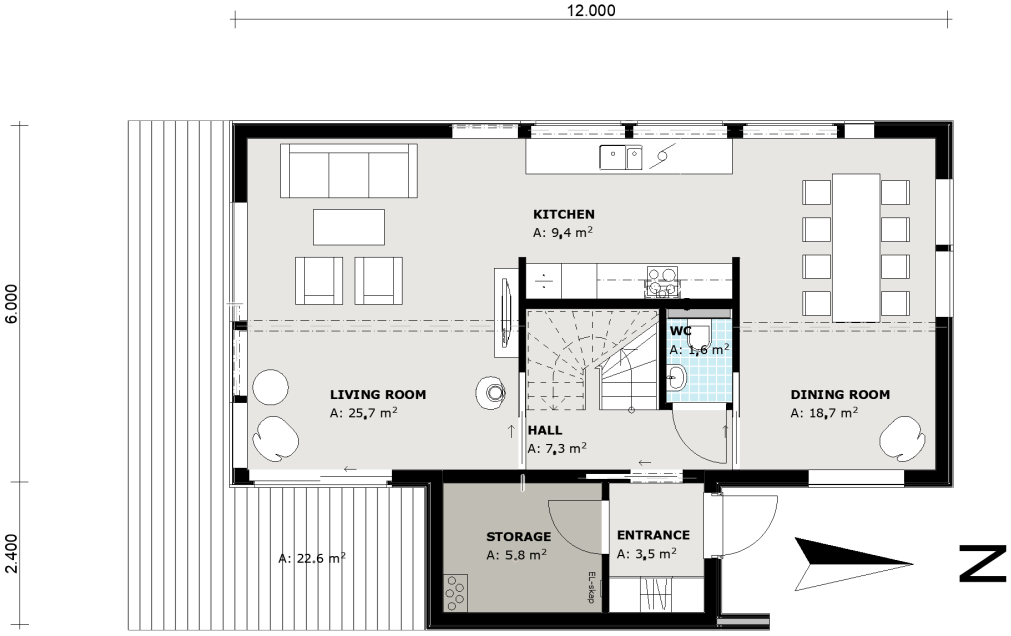

Figure 6. Ground floor layout (source: Norgeshus). 


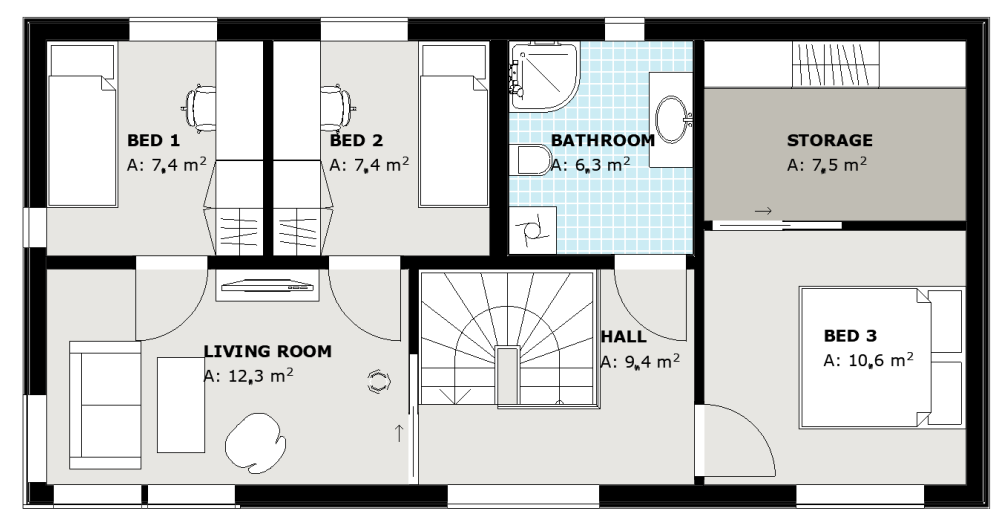

Figure 7. First floor layout (source: Norgeshus).

The reference model is created with energy measures listed in Table 2. Internal gains from the occupants, equipment and lighting are defined according to the values set in the Norwegian standard, SN-NSPEK 3031:2020 [23]. The deterministic occupancy schedule is based on schedules from Nord et al. [24] and adapted to fit the annual normalized values in the standard. By default, the reference model is applied with internal blinds that are PI-controlled with activation when the operative indoor temperature reaches $23^{\circ} \mathrm{C}$. Windows open when the operative temperature exceeds $25^{\circ} \mathrm{C}$.

Table 2. Input values regarding the building body for reference model.

\begin{tabular}{cc}
\hline Input Parameter & Values for Reference Case \\
\hline U-value exterior walls (200 mm insulation) & $0.20 \mathrm{~W} / \mathrm{m}^{2} \mathrm{~K}$ \\
\hline U-value roof (400 mm insulation) & $0.13 \mathrm{~W} / \mathrm{m}^{2} \mathrm{~K}$ \\
\hline U-value floor (350 mm insulation) & $0.09 \mathrm{~W} / \mathrm{m}^{2} \mathrm{~K}$ \\
\hline U-value windows and doors & $0.90 \mathrm{~W} / \mathrm{m}^{2} \mathrm{~K}$ \\
\hline Window and door ratio of treated area & $36 \%$ \\
\hline Efficiency of heat recovery & $80 \%$ \\
\hline Air leakage rate per hour at 50 Pa pressure difference & $1.0 \mathrm{~h}^{-1}$ \\
\hline Normalized thermal bridge coefficient & $0.05 \mathrm{~W} / \mathrm{m}^{2} \mathrm{~K}$ \\
\hline
\end{tabular}

\subsection{Software}

The building performance simulations were conducted using the software IDA-ICE. IDA ICE is a building energy modeling software for energy and indoor climate developed by EQUA Simulation AB [25]. The software can perform detailed calculation of the energy use and indoor thermal climate by using a whole year dynamic multi-zone simulation. For the case study, IFC-models from ArchiCAD were imported to IDA-ICE with slight modifications through SimpleBIM. SimpleBIM has an add-on, which addresses compatibility issues with IDA-ICE and enables the possibility of modifying the model to be validated for usage in IDA-ICE.

The daylight calculations were executed with the integrated Radiance engine [26]. In order to facilitate results, which are easily comparable to both the Norwegian regulations and the European standards, only the DF was examined. The DF presumes the illumination on a horizontal reference plane in the room expressed in percentage of the simultaneous illumination on an outdoor horizontal plane with no casting shadows [27]. This is a simpler approach than a dynamic, climate derived illuminance calculation. The DF method assumes a calculation of a CIE overcast sky, and is therefore independent of the window orientation. For this sky model, the luminance changes with altitude and is three times as bright at the zenith than near the horizon [28]. Even though this method does not 
comply with the actual daylight environment, it still represents the unfavorable case and will unlikely give results better than the actual daylight performance [29].

As previously mentioned, TEK17 gives two functional requirements for thermal comfort. The guidance for fulfillment of the functional requirements states that the performance is adequate if the exceedance of the highest temperatures does not surpass $50 \mathrm{~h}$ in a normal year. The acceptance criterion for NS 16798 is based on CIBSE TM52, where the limit of unacceptable hours is set to be $3 \%$ of the occupancy hours [21]. In other words, based on used occupancy schedule, this corresponds to a maximum of $86 \mathrm{~h}$ for daily rooms and 125 $\mathrm{h}$ for bedrooms.

\subsection{Simulated Cases}

Ten alternative cases are presented in Table 3. The reference model is named Case 0 and is equal to the distributed model from Norgeshus. Case 1 aims to investigate the effect of only changing the orientation of the building, which is relevant for a lot of building scenarios. This is done by orienting the longer facade to the south. A typical measure for pursuing a better energy efficiency is improving the building envelope by adding more insulation. Thus, Case 2 investigates this scenario. Adding more insulation results in thicker walls, which influences the daylight distribution. Case 3 and Case 4 represent cases equal to the boundary criteria that are allowed for the simplified method in §13-7(2) TEK17. Case 5, Case 6 and Case 8 investigate measures for solar control. The different glazing properties is a relevant aspect concerning both the transmitted daylight and solar radiation. Since the DF is calculated for an overcast sky, the effect of having different shading strategies is neglected since it does not influence the daylight calculation. A revised window design, Case 7, aims to discover how strategically changing the window design affects the performance of the same building body. All the windows facing north are removed, and some are removed on the western and eastern facade, while more windows are placed on the southern facade. The reason for this is to try to minimize the heat losses through the windows, and exploit as much of the passive solar heating as possible. Case 9 and Case 10 investigate the effect of new technologies based on discoveries from Lee et al. [18]. One of the findings is that an inclination of $-10^{\circ}$ has the most PV-production, hence the choice of two alternative cases for comparison. For each case alternative, only the mentioned parameter changes are applied. The remaining model is equivalent to the reference model.

Table 3. Overview of simulated cases.

\begin{tabular}{|c|c|c|}
\hline Case $\mathrm{Nr}$ & Case Name & Case Description \\
\hline Case 0 & Reference model & Original model with default values \\
\hline Case 1 & Changed orientation & Building model is rotated 90 degrees counter-clockwise \\
\hline Case 2 & Thicker walls & Improving the building envelope. $350 \mathrm{~mm}$ insulation in walls \\
\hline Case 3 & Shading object & $\begin{array}{l}\text { Maximum accepted obstruction angle in the horizon for the } \\
\text { simplified method in TEK17 }\end{array}$ \\
\hline Case 4 & Minimum glazing area & $\begin{array}{l}\text { Minimum glazing criterion for the simplified method in TEK17 for } \\
\text { each room }\end{array}$ \\
\hline Case 5 & Low light transmittance & New glazing properties: LT = 27 and g-factor: 16 \\
\hline Case 6 & Medium light transmittance & New glazing properties: LT $=61$ and g-factor: 33 \\
\hline Case 7 & Revised window design & Removal of windows facing north, and more windows facing south \\
\hline Case 8 & Static external overhang & External overhang with depth of $1 \mathrm{~m}$ \\
\hline Case 9 & Light shelf with PV-module (horizontal) & Mounted on windows $>1 \mathrm{~m}$ wide \\
\hline Case 10 & Light shelf with PV-module $\left(-10^{\circ}\right.$ inclination $)$ & Mounted on windows $>1 \mathrm{~m}$ wide. Rotated $10^{\circ}$ toward the sun. \\
\hline
\end{tabular}




\section{Results}

In the following section, the simulation results are presented. Each case alternative is evaluated in terms of the annual heating demand, daylight and thermal comfort. While energy is displayed collectively on a single table, daylight and thermal comfort are presented in representative tables and figures relevant to the studied rooms in the building.

\subsection{Energy}

The simulated heating demand is expressed as the total energy need for space heating, including ventilation. An overview of the annual heating demand for each case is presented in Table 4. As expected, the better insulated walls in Case 2 and reduction in window area in Case 4 decrease the need for annual heating. A decrease of almost $27 \%$ for Case 2 is a quite significant performance increase for the building. Just by optimizing the window design, as in Case 7 with the revised window design, there is a profit of $7.5 \mathrm{kWh} / \mathrm{m}^{2}$ annually. The light shelves themselves do not influence the energy performance significantly, but there is an advantage in the production of electricity, which can be utilized. The implementation of such an installation is rather based on an expected cost-benefit perspective.

Table 4. Heating demand for every case.

\begin{tabular}{clc}
\hline Case Number & Case Name & $\begin{array}{c}\text { Annual Heating Demand } \\
\left(\mathbf{k W h} / \mathbf{m}^{\mathbf{2}}\right)\end{array}$ \\
\hline Case 0 & Reference model & 43.9 \\
\hline Case 1 & Changed orientation & 42.9 \\
\hline Case 2 & Thicker walls & 32.2 \\
\hline Case 3 & Shading object & 55.1 \\
\hline Case 4 & Minimum glazing area & 36.2 \\
\hline Case 5 & Low light transmittance & 59.6 \\
\hline Case 6 & Medium light transmittance & 50.7 \\
\hline Case 7 & Revised window design & 36.4 \\
\hline Case 8 & Static external overhang & 45.4 \\
\hline Case 9 & Light shelf with PV-module (horizontal) & $42.6-3.7$ PV-production \\
\hline Case 10 & $\begin{array}{l}\text { Light shelf with PV-module (-10 } \\
\text { inclination) }\end{array}$ & $43.7-4.8$ PV-production \\
\hline
\end{tabular}

\subsection{Daylight}

Based on the results for daylight performance, bedroom 2 and bedroom 3 are the worst performing rooms. A possible reason for this may be that these rooms have one-sided light transmittance, and the geometry of these rooms regulates how the light is distributed. Case 4 and Case 5 have obvious issues regarding adequate daylight provision. Furthermore, it is worth noticing that Case 4 is designed with the minimum, defined by the simplified method in TEK17, and it is not approved by any of the used criteria in this paper. A horizontal light shelf obtains a slight decrease in daylight provision, but does not deviate from the reference case concerning criteria acceptance. The rotated light shelf, Case 10, performs similarly but gives more profit with PV-production.

The results for daylight are calculated for each individual room considered. The results are evaluated according to criteria set in TEK17 $(\overline{D F}=2.0 \%)$ and NS-EN 17037 (50\% of area $\geq D_{T}=2.4 \%$ and $95 \%$ of area $\geq D_{T M}=0.8 \%$ ). The following Figures 8-14 display the results for each room with respect to the mentioned criteria. 


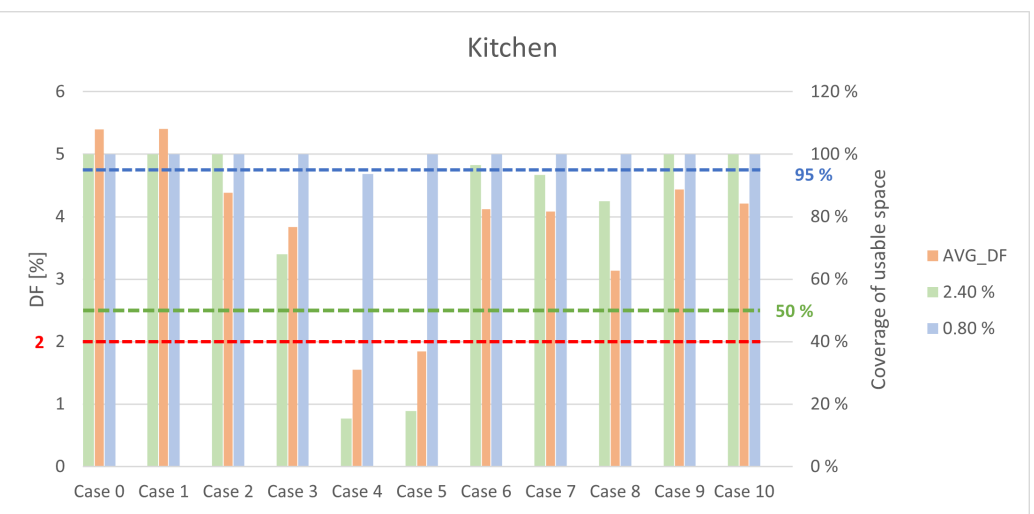

Figure 8. Simulation results for average daylight factor-kitchen.

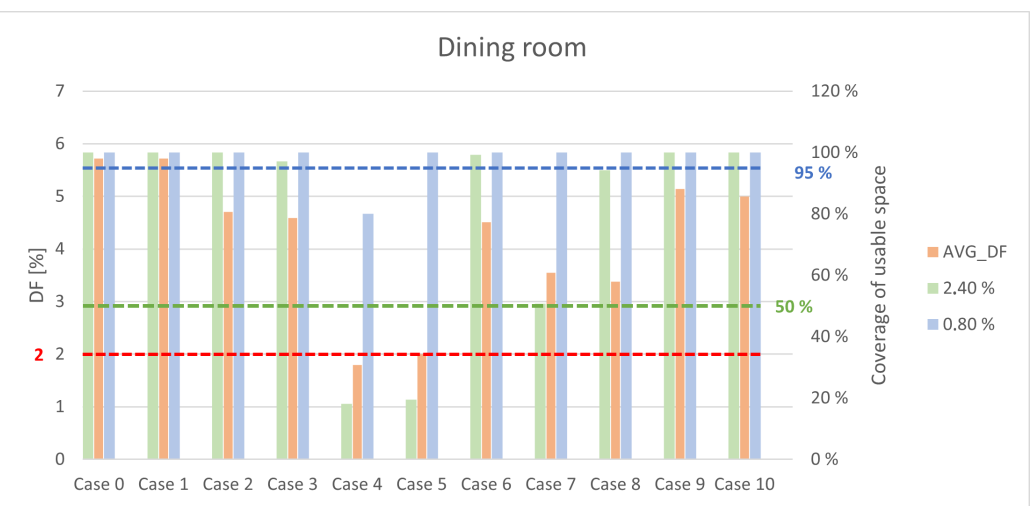

Figure 9. Simulation results for average daylight factor-dining room.

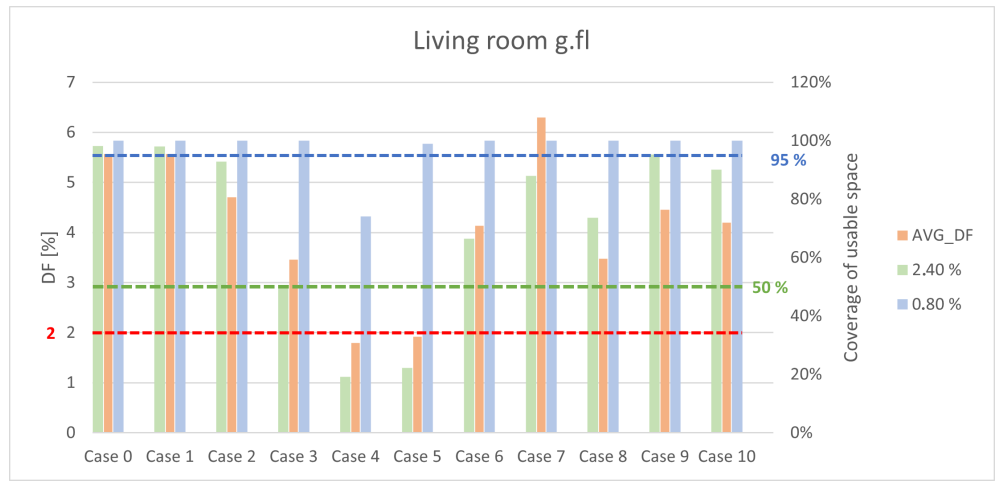

Figure 10. Simulation results for average daylight factor-living room ground floor.

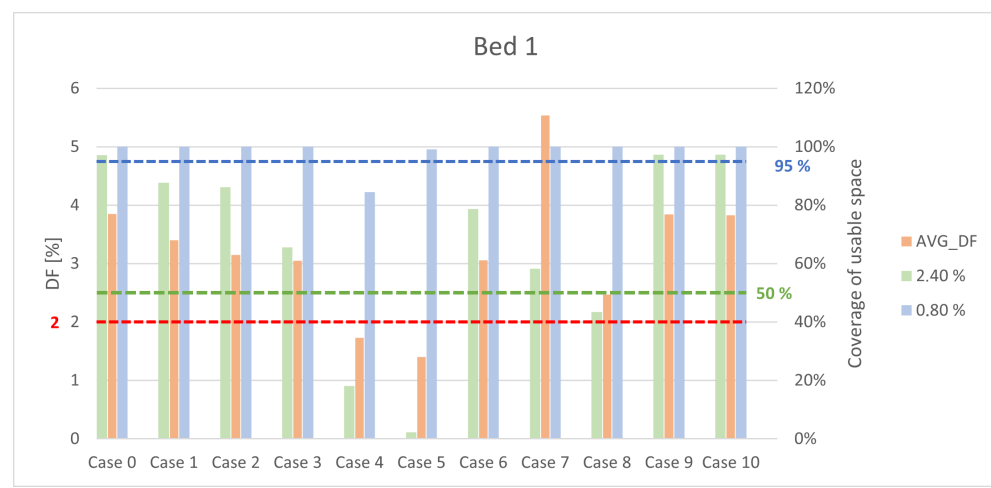

Figure 11. Simulation results for average daylight factor-bed 1. 


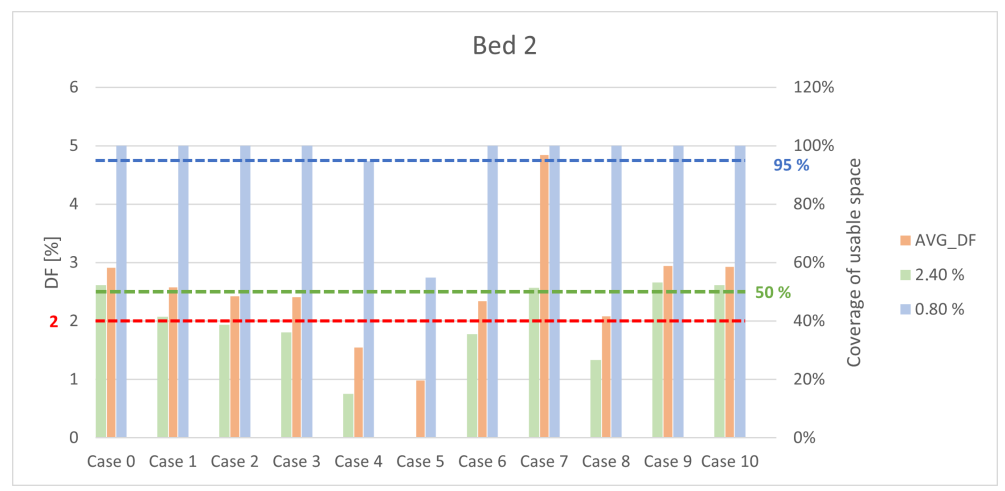

Figure 12. Simulation results for average daylight factor-bed 2.

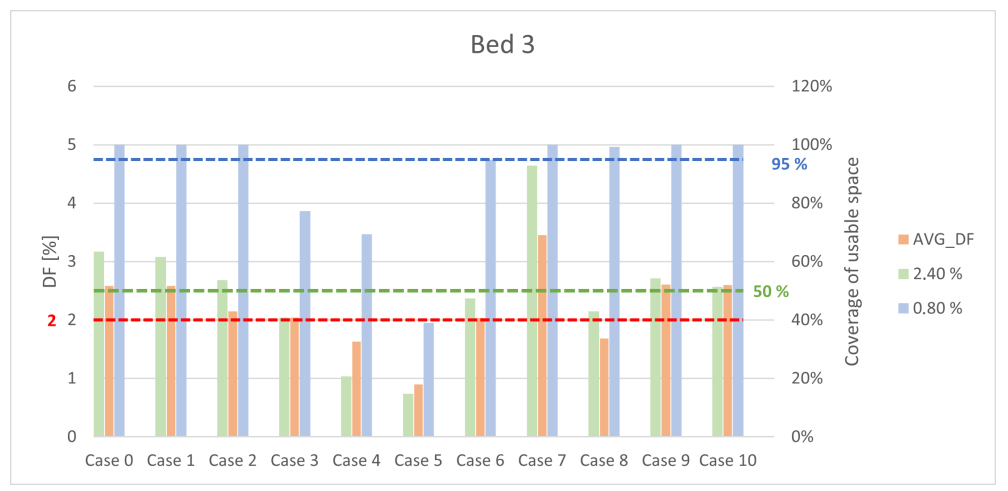

Figure 13. Simulation results for average daylight factor-bed 3.

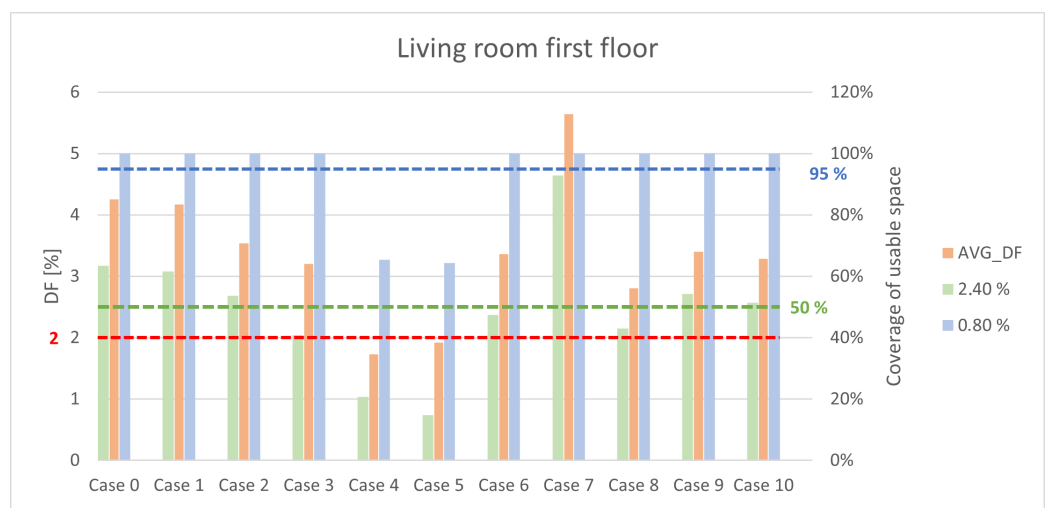

Figure 14. Simulation results for average daylight factor-living room first floor.

\subsection{Thermal Comfort}

By default, the reference model does not satisfy the expected performance regarding overheating hours in TEK17; see Table 5. The following Tables 5-15 present the simulated results for each case, where green represents the satisfied values, red the unapproved values, and yellow the values close to the acceptance level. In contrast to the significant improvement in energy performance for Case 2, thicker walls lead to more severe overheating risk as illustrated in Table 7 . Reduction of the glazing area, Case 4, or improving glazing properties tends to be the most effective measure. Case 6, medium light transmittance, is a more reasonable measure than Case 5, low light transmittance, since the latter has poor performance both for efficient energy use and access to daylight. The revised window design in Case 7 gives a slight overall improvement but still is not satisfactory for bedroom 2 and living room on first floor. Table 13 for Case 8, static external overhang, shows that static external shading gives good results, and the unapproved rooms fails by a small margin. The light shelves do not influence the thermal comfort performance very much. 
For most of the cases, there is a correlation between a good energy performance and a bad thermal comfort performance and vice versa.

Table 5. Thermal comfort for Case 0-Reference model.

\begin{tabular}{ccc}
\hline & \multicolumn{3}{c}{ IDA-ICE } \\
\cline { 2 - 3 } & Hours Exceeding $\mathbf{2 6}{ }^{\circ} \mathbf{C} \mathbf{~ ( h )}$ & Unacceptable Hours (IV) (h) \\
\hline Kitchen & 67 & 53 \\
\hline Dining room & 69 & 38 \\
\hline Living room g.fl & 54 & 67 \\
\hline Bed 1 & 75 & 163 \\
\hline Bed 2 & 78 & 172 \\
\hline Bed 3 & 43 & 13 \\
\hline Living room 1. fl & 61 & 79 \\
\hline
\end{tabular}

Table 6. Thermal comfort for Case 1—Rotated 90 degrees counter-clockwise.

\begin{tabular}{ccc}
\hline & \multicolumn{2}{c}{ IDA-ICE } \\
\cline { 2 - 3 } & Hours Exceeding $\mathbf{2 6}{ }^{\circ} \mathbf{C} \mathbf{~ ( h )}$ & Unacceptable Hours (IV) (h) \\
\hline Kitchen & 61 & 44 \\
\hline Dining room & 86 & 69 \\
\hline Living room g.fl & 49 & 28 \\
\hline Bed 1 & 55 & 65 \\
\hline Bed 2 & 65 & 91 \\
\hline Bed 3 & 35 & 10 \\
\hline Living room 1. fl & 45 & 46 \\
\hline
\end{tabular}

Table 7. Thermal comfort for Case 2-Improved building envelope.

\begin{tabular}{ccc}
\hline & \multicolumn{3}{c}{ IDA-ICE } \\
\cline { 2 - 3 } & Hours Exceeding $\mathbf{2 6}{ }^{\circ} \mathbf{C}(\mathbf{h})$ & Unacceptable Hours (IV) (h) \\
\hline Kitchen & 77 & 64 \\
\hline Dining room & 69 & 47 \\
\hline Living room g.fl & 78 & 82 \\
\hline Bed 1 & 75 & 167 \\
\hline Bed 2 & 78 & 194 \\
\hline Bed 3 & 43 & 18 \\
\hline Living room 1. fl & 60 & 97 \\
\hline
\end{tabular}

Table 8. Thermal comfort for Case 3-Maximum accepted obstructing shading object TEK17.

\begin{tabular}{ccc}
\hline & \multicolumn{3}{c}{ IDA-ICE } \\
\cline { 2 - 3 } & Hours Exceeding $\mathbf{2 6}{ }^{\circ} \mathbf{C}$ (h) & Unacceptable Hours (IV) (h) \\
\hline Kitchen & 45 & 8 \\
\hline Dining room & 46 & 6 \\
\hline Living room g.fl & 47 & 57 \\
\hline Bed 1 & 57 & 57 \\
\hline Bed 2 & 59 & 9 \\
\hline Bed 3 & 37 & 36 \\
\hline Living room 1. fl & 53 & 57 \\
\hline
\end{tabular}


Table 9. Thermal comfort for Case 4-Minimum glazing criterion TEK17.

\begin{tabular}{ccc}
\hline & \multicolumn{3}{c}{ IDA-ICE } \\
\cline { 2 - 3 } & Hours Exceeding $\mathbf{2 6}{ }^{\circ} \mathbf{C}$ (h) & Unacceptable Hours (IV) (h) \\
\hline Kitchen & 31 & 2 \\
\hline Dining room & 29 & 2 \\
\hline Living room g.fl & 32 & 2 \\
\hline Bed 1 & 47 & 79 \\
\hline Bed 2 & 58 & 117 \\
\hline Bed 3 & 25 & 8 \\
\hline Living room 1. fl & 44 & 31 \\
\hline
\end{tabular}

Table 10. Thermal comfort for case 5-LT: 27 and g-factor: 16.

\begin{tabular}{ccc}
\hline & \multicolumn{3}{c}{ IDA-ICE } \\
\cline { 2 - 3 } & Hours Exceeding $\mathbf{2 6}{ }^{\circ} \mathbf{C}(\mathbf{h})$ & Unacceptable Hours (IV) (h) \\
\hline Kitchen & 26 & 0 \\
\hline Dining room & 24 & 0 \\
\hline Living room g.fl & 25 & 0 \\
\hline Bed 1 & 37 & 19 \\
\hline Bed 2 & 39 & 20 \\
\hline Bed 3 & 20 & 4 \\
\hline Living room 1. fl & 31 & 12 \\
\hline
\end{tabular}

Table 11. Thermal comfort for case 6-LT: 61 and g-factor: 33.

\begin{tabular}{ccc}
\hline & \multicolumn{3}{c}{ IDA-ICE } \\
\cline { 2 - 3 } & Hours Exceeding $\mathbf{2 6}{ }^{\circ} \mathbf{C}(\mathbf{h})$ & Unacceptable Hours (IV) (h) \\
\hline Kitchen & 43 & 12 \\
\hline Dining room & 42 & 7 \\
\hline Living room g.fl & 40 & 13 \\
\hline Bed 1 & 52 & 67 \\
\hline Bed 2 & 52 & 73 \\
\hline Bed 3 & 29 & 7 \\
\hline Living room 1. fl & 44 & 33 \\
\hline
\end{tabular}

Table 12. Thermal comfort for Case 7-Revised window design.

\begin{tabular}{ccc}
\hline & \multicolumn{3}{c}{ IDA-ICE } \\
\cline { 2 - 3 } & Hours Exceeding $\mathbf{2 6}{ }^{\circ} \mathbf{C} \mathbf{~ ( h )}$ & Unacceptable Hours (IV) (h) \\
\hline Kitchen & 55 & 26 \\
\hline Dining room & 47 & 14 \\
\hline Living room g.fl & 56 & 61 \\
\hline Bed 1 & 45 & 79 \\
\hline Bed 2 & 63 & 136 \\
\hline Bed 3 & 33 & 11 \\
\hline Living room 1. fl & 86 & 131 \\
\hline
\end{tabular}


Table 13. Thermal comfort for Case 8-Static external overhang.

\begin{tabular}{ccc}
\hline & \multicolumn{2}{c}{ IDA-ICE } \\
\cline { 2 - 3 } & Hours Exceeding $\mathbf{2 6}{ }^{\circ} \mathbf{C} \mathbf{~ ( h )}$ & Unacceptable Hours (IV) (h) \\
\hline Kitchen & 56 & 26 \\
\hline Dining room & 53 & 21 \\
\hline Living room g.fl & 50 & 43 \\
\hline Bed 1 & 60 & 129 \\
\hline Bed 2 & 64 & 122 \\
\hline Bed 3 & 32 & 10 \\
\hline Living room 1. fl & 46 & 54 \\
\hline
\end{tabular}

Table 14. Thermal comfort for Case 9-Light shelf (horizontal).

\begin{tabular}{|c|c|c|}
\hline & \multicolumn{2}{|c|}{ IDA-ICE } \\
\hline & Hours over $26^{\circ} \mathrm{C}(\mathrm{h})$ & Unacceptable Hours (IV) (h) \\
\hline Kitchen & 62 & 33 \\
\hline Dining room & 66 & 32 \\
\hline Living room g.fl & 50 & 48 \\
\hline Bed 1 & 74 & 155 \\
\hline Bed 2 & 77 & 164 \\
\hline Bed 3 & 43 & 14 \\
\hline Living room $1 . \mathrm{fl}$ & 56 & 71 \\
\hline
\end{tabular}

Table 15. Thermal comfort for Case 10 — Light shelf (rotated 10 degrees toward the sun).

\begin{tabular}{ccc}
\hline & \multicolumn{3}{c}{ IDA-ICE } \\
\cline { 2 - 3 } & Hours over $\mathbf{2 6}{ }^{\circ} \mathbf{C}$ (h) & Unacceptable Hours (IV) (h) \\
\hline Kitchen & 55 & 34 \\
\hline Dining room & 63 & 32 \\
\hline Living room g.fl & 47 & 50 \\
\hline Bed 1 & 74 & 155 \\
\hline Bed 2 & 77 & 166 \\
\hline Bed 3 & 43 & 14 \\
\hline Living room 1. fl & 62 & 70 \\
\hline
\end{tabular}

\section{Conclusions}

In light of the analysis, optimizing window design is a necessary measure since it contributes to a significant decrease in the energy demand for heating and cooling, providing a balance in terms of optimal conditions for thermal comfort and daylight, in cold climates as well. The results presented for Case 2, with thicker walls, indicate that focusing primarily on well-insulated and more air-tight walls does not exclude the possibility that a significant risk of overheating can occur if a conscious window design is not included, which further confirms the findings by Tian and Hrynyszyn [17]. This means that technical regulations at the national level should include extended and clearly defined requirements, including thermal comfort and daylight to provide more holistic and sustainable solutions for housing, especially in terms of the expected climate changes.

By performing a revision of window design, the overall performance of the building improves. This indicates that daylight should be considered holistically from the initial stages. By having the window design in mind in the initial stages of planning, it can result not only in better daylight provision, but also in improved energy and thermal comfort performance because they tie together.

Optimized window design, including consideration for daylight, thermal comfort and energy is necessary to achieve an overall, optimal energy performance of a building. Table 16 presents an overview of the findings from the analyzed cases. The overview shows that each case individually does not fully satisfy all aspects, and there is still a potential for 
energy savings to achieve a level of zero energy building (ZEB) by optimizing the building envelope parameters. A more optimized version should therefore be reviewed, and this will be a subject of future work.

Table 16. Comparison of the analyzed cases.

\begin{tabular}{|c|c|c|c|}
\hline Case $\mathrm{Nr}$ & Daylight & Thermal Comfort & $\begin{array}{c}\text { Energy: Annual Heating } \\
\text { Demand }\left(\mathrm{kWh} / \mathrm{m}^{2}\right)\end{array}$ \\
\hline $\begin{array}{l}\text { Case 0: Reference model } \\
\text { Original model with default } \\
\text { values }\end{array}$ & Good performance & Poor performance & 43.9 \\
\hline $\begin{array}{l}\text { Case 1: Changed orientation } \\
\text { Building model is rotated } 90 \\
\text { degrees counter-clockwise }\end{array}$ & Good performance & Poor performance & 42.9 \\
\hline $\begin{array}{l}\text { Case 2: Thicker walls } \\
\text { Improving the building } \\
\text { envelope. } 350 \mathrm{~mm} \text { insulation } \\
\text { in walls }\end{array}$ & Good performance & Very poor performance & 32.2 \\
\hline $\begin{array}{l}\text { Case 3: Shading object } \\
\text { Maximum accepted } \\
\text { obstruction angle in the } \\
\text { horizon for the simplified } \\
\text { method in TEK17 }\end{array}$ & Poor performance & Poor performance & 55.1 \\
\hline $\begin{array}{l}\text { Case 4: Minimum glazing area } \\
\text { Minimum glazing criterion for } \\
\text { the simplified method in } \\
\text { TEK17 for each room }\end{array}$ & Very poor performance & Good performance & 36.2 \\
\hline $\begin{array}{l}\text { Case 5: Low light } \\
\text { transmittance New glazing } \\
\text { properties: } \mathrm{LT}=27 \text { and } \\
\text { g-factor: } 16\end{array}$ & Very poor performance & Very good performance & 59.6 \\
\hline $\begin{array}{l}\text { Case 6: Medium light } \\
\text { transmittance New glazing } \\
\text { properties: } \mathrm{LT}=61 \text { and } \\
\text { g-factor: } 33\end{array}$ & Ok performance & Good performance & 50.7 \\
\hline $\begin{array}{l}\text { Case 7: Revised window } \\
\text { design Removal of windows } \\
\text { facing north, and more } \\
\text { windows facing south }\end{array}$ & Very good performance & Ok performance & 36.4 \\
\hline $\begin{array}{l}\text { Case 8: Static external } \\
\text { overhang External overhang } \\
\text { with depth of } 1 \mathrm{~m}\end{array}$ & Ok performance & Ok performance & 45.4 \\
\hline $\begin{array}{l}\text { Case 9: Light shelf with } \\
\text { PV-module (horizontal) } \\
\text { Mounted on windows }>1 \mathrm{~m} \\
\text { wide }\end{array}$ & Good performance & Poor performance & 42.6-3.7 PV-production \\
\hline $\begin{array}{l}\text { Case 10: Light shelf with } \\
\text { PV-module }\left(-10^{\circ} \text { inclination }\right) \\
\text { Mounted on windows }>1 \mathrm{~m} \\
\text { wide Rotated } 10^{\circ} \text { toward the } \\
\text { sun. }\end{array}$ & Good performance & Poor performance & 43.7-4.8 PV-production \\
\hline
\end{tabular}

There should be paid more attention to which criteria are to be used for daylight calculation, as the criteria are not consistent. According to the simulated results presented in this paper, the simplified method in TEK17 gives acceptance of criteria, which neither the average daylight factor nor the criteria in NS-EN 17037 approve. A theoretical combination with Case 3, maximum accepted obstruction, which also is accepted by the simplified method, would give even worse daylight performance. A simplified method should be the most conservative alternative and give the oversized alternative, while the advanced method should be optimized closer to the acceptable limit. 
In light of the findings in this study, the criteria for thermal comfort and daylight, if clearly defined, can affect the energy demand for heating and cooling as well as the indoor climate. It is concerning that the regulations are not consistent; revisions should be taken into account at the national level.

Author Contributions: Conceptualization, T.-A.A. and B.D.H.; software, T.-A.A.; visualization, T.-A.A.; methodology, T.-A.A.; writing—original draft preparation and editing, T.-A.A.; supervision, B.D.H.; project administration, B.D.H.; writing—review and editing, B.D.H. All authors have read and agreed to the published version of the manuscript.

Funding: This research received no external funding.

Acknowledgments: The authors would like to thank Norgeshus for providing data for the analyzed building.

Conflicts of Interest: The authors declare no conflict of interest.

\section{References}

1. Ko, W.H.; Brager, G.; Schiavon, S.; Selkowitz, S. Building Envelope Impact on Human Performance and Well-Being: Experimental Study on View Clarity; Center for the Built Environment, UC Berkeley: Berkeley, CA, USA, 2017.

2. RIF. Dagslys i Bygninger-Beste Praksis i Byggeprosjekter og Forslag til Utvikling av Regelverket. Available online: https: / / www.rif.no/wp-content/uploads/2020/02/Dagslys-februar-2020.pdf (accessed on 25 May 2021).

3. SINTEF and KanEnergi. Mulighetsstudie-Solenergi i Norge. Available online: https:/ / docplayer.me/196384-Mulighetsstudiesolenergi-i-norge.html (accessed on 12 April 2021).

4. Lavenergiprogrammet. Solenergi. Available online: https://www.tekna.no/fag-og-nettverk/bygg-og-anlegg/byggbloggen/ solenergi/ (accessed on 12 April 2021).

5. Rindal, L.B.; Salvesen, F. Solenergi for Varmeformål—Snart Lønnsomt? NVE: Oslo, Norway, 2008; Volume 10.

6. Wirz-Justice, A.; Skene, D.J.; Münch, M. The relevance of daylight for humans. Biochem. Pharmacol. 2020, 191, 114304. [CrossRef] [PubMed]

7. Kauffman, J. Benefits of Vitamin D supplementation. J. Am. Physicians Surg. 2009, 14, 38-45.

8. Lansdowne, A.T.G.; Provost, S.C. Vitamin D3 enhances mood in healthy subjects during winter. Psychopharmacology 1998, 135, 319-323. [CrossRef] [PubMed]

9. Vandewalle, G.; Maquet, P.; Dijk, D.-J. Light as a modulator for cognitive brain function. Trends Cogn. Sci. 2009, 10, 429-438. [CrossRef] [PubMed]

10. Taubøll, H.; Østby, E. Innebærer Endring i Byggteknisk Forskrift at Solforhold Ikke Lengre må tas Hensyn Til? Available online: https:/ / www.estatenyheter.no/innebaerer-endring-i-byggeteknisk-forskrift-at-solforhold-ikke-lenger-ma-tas-hensyntil/281277 (accessed on 23 May 2021).

11. Sepúlveda, A.; De Luca, F.; Thalfeldt, M.; Kurnitski, J. Analyzing the fulfillment of daylight and overheating requirements in residential and office buildings in Estonia, Building and Environment. Build. Environ. 2020, 180, 107036. [CrossRef]

12. Standard Norge. NS-EN 17037:2018 Dagslys i Bygninger; Standard Norge: Oslo, Norway, 2019.

13. Goto, T.; Toftum, J.; De Dear, R.; Fanger, P.O. Thermal sensation and comfort with transient metabolic rates. Indoor Air 2002, 1, 1038-1043.

14. SMHI. Climate Indicators-Temperature. Available online: http://www.smhi.se/en/climate/climate-indicators/climateindicators-temperature-1.91472 (accessed on 10 July 2021).

15. Smiljanic, I.; Lancaster, S.; Barroso, C.; Trigo, I.; Salentinig, A.; Prieto, J. Maximum Temperature Records Were Broken in Many Parts of Europe in June and July 2019, Due to a Series of Heatwaves. EUMETSAT. 2019. Available online: https: / / www.eumetsat.int/european-heatwaves-summer-2019 (accessed on 22 May 2021).

16. Li, X.; Taylor, J.; Symonds, P. Indoor overheating An d mitigation of converted lofts in London, UK. Build. Serv. Eng. Res. Technol. 2019, 40-4, 409-425. [CrossRef]

17. Tian, Z; Hrynyszyn, B.D. Overheating risk of a typical Norwegian residential building retrofitted to higher energy standards under future climate conditions. In E3S Web of Conferences; EDP Sciences: Les Ulis, France, 2020; Volume 172.

18. Lee, H.; Zhao, X.; Seo, J. A Study of Optimal Specifications for Light Shelves with Photovoltaic Modules to improve Indoor Comfort and Save Building Energy. IJERPH Environ. Sci. Eng. 2021, 18, 2574. [CrossRef]

19. Direktoratet for Byggkvalitet. Byggteknisk Forskrift (TEK17): Kapittel 13-7 Lys og Utsyn. Available online: https:/ / dibk.no/ regelverk/byggteknisk-forskrift-tek17/13/v/13-7/ (accessed on 23 March 2021).

20. Standard Norge. NS-EN 12464-1:2011 Lys og Belysning, Belysning av Arbeidsplasser, Del 1: Innendørs Arbeidsplasser; Standard Norge: Oslo, Norway, 2011.

21. CIBSE. The Limits of Thermal Comfort: Avoiding Overheating in European Buildings. Available online: https://www.cibse.org/ knowledge/knowledge-items / detail?id=a0q20000008I7f5AAC (accessed on 22 May 2021). 
22. Standard Norge. NS-EN 16798-1:2019 Bygningers Energiytelse. Ventilasjon i Bygninger. Del 1: Inneklimaparametre for Dimensjonering og Vurdering av Bygningers Energiytelse Inkludert Inneluftkvalitet, Termisk Miljø, Belysning og Akustikk (Modul M1-6); Standard Norge: Oslo, Norway, 2019.

23. Standard Norge. SN-NSPEK 3031:2020 Bygningers Energiytelse-Beregning av Energibehov og Energiforsyning; Standard Norge: Oslo, Norway 2020.

24. Nord, N.; Tereschenko, T.; Qvistgaard, L.H.; Tryggestad, I.S. Influence of occupant behavior and operation on performance of a residential Zero Emission Building in Norway. Energy Build. 2018, 159 75-88. [CrossRef]

25. EQUA. IDA Indoor Climate and Energy. Available online: https://www.equa.se/en/ida-ice (accessed on 24 March 2021).

26. EQUA. Daylight. Available online: https://www.equa.se/en/ida-ice/extensions/daylight (accessed on 23 May 2021).

27. Thue, J.V. Bygningsfysikk; Fagbokforlaget: Bergen, Norway, 2016; pp. 438-439.

28. CLEAR. Sky Types. Available online: https://www.new-learn.info/packages/clear/visual/daylight/sun\$_\} $\$$ sky/sky $\$\{\}$ \}types. html (accessed on 19 April 2021).

29. Lee, J.; Boubekri, M.; Liang, F. Impact of Building Design Parameters on Daylighting Metrics Using an Analysis, Prediction, and Optimization Approach Based on Statistical Learning Technique. Sustain. Lighting Front. Sustain. Dev. 2019, $11,1474$. [CrossRef] 